\title{
Striped-tailed Yellow-finch nesting success in abandoned mining pits from central Brazilian cerrado
}

\author{
Gressler, DT. ${ }^{a *}$ and Marini, $M \hat{A}^{b}$ \\ aPrograma de Pós-Graduação em Ecologia, Instituto de Ciências Biológicas, Universidade de Brasília - UnB, Asa Norte, \\ Campus Universitário Darcy Ribeiro, CEP 70910-900, Brasília, DF, Brazil \\ ${ }^{\text {b} D e p a r t a m e n t o ~ d e ~ Z o o l o g i a, ~ I n s t i t u t o ~ d e ~ C i e ̂ n c i a s ~ B i o l o ́ g i c a s, ~ U n i v e r s i d a d e ~ d e ~ B r a s i ́ l i a ~-~ U n B, ~ A s a ~ N o r t e, ~}$ \\ Campus Universitário Darcy Ribeiro, CEP 70910-900, Brasília, DF, Brazil \\ *e-mail: dtgressler@hotmail.com
}

Received: June 18, 2013 - Accepted: October 25, 2013 - Distributed: March 31, 2015

\begin{abstract}
Suitability of degraded areas as breeding habitats can be tested through assessment of nest predation rates. In this study we estimated nest success in relation to several potential predictors of nest survival in the Stripe-tailed Yellowfinch (Sicalis citrina) breeding in abandoned mining pits at Brasília National Park. We monitored 73 nests during the 2007-breeding season. Predation was the main cause of nest failure $(n=48,66 \%)$; while six nests were abandoned $(8 \%)$ and 19 nests produced young $(26 \%)$. Mayfield's daily survival rates and nest success were 0.94 and $23 \%$, respectively. Our results from nest survival models on program MARK indicated that daily survival rates increase linearly towards the end of the breeding season and decrease as nests aged. None of the nest individual covariates we tested - nest height, nest size, nest substrate, and edge effect - were important predictors of nest survival; however, nests placed on the most common plant tended to have higher survival probabilities. Also, there was no observer effect on daily survival rates. Our study suggests that abandoned mining pits may be suitable alternative breeding habitats for Striped-tailed Yellow-finches since nest survival rates were similar to other studies in the central cerrado region.
\end{abstract}

Keywords: nest survival, Emberizidae, breeding habitat, degraded habitat, neotropical savanna.

\section{Sucesso reprodutivo de Sicalis citrina em cascalheiras abandonadas, região central do Cerrado}

\begin{abstract}
Resumo
A adequação de habitats degradados para reprodução de aves pode ser testada por meio de avaliação das taxas de predação de ninhos. Neste estudo nós estimamos o sucesso de nidificação do canário-rasteiro (Sicalis citrina) e o relacionamos, por meio de modelagem no programa MARK, com diversos fatores que potencialmente afetam a sobrevivência dos ninhos da espécie em antigas áreas de extração de solo (cascalheiras), no Parque Nacional de Brasília, Distrito Federal. Nós monitoramos 73 ninhos da espécie durante a estação reprodutiva de 2007. Predação foi a principal causa da perda de ninhos ( $\mathrm{n}=48,66 \%)$, enquanto seis foram abandonados ( $8 \%)$ e 19 produziram ao menos um filhote $(26 \%)$. A taxa diária de sobrevivência e o sucesso total de Mayfield foram 0,94 and 23\%, respectivamente. Nossos resultados, obtidos da modelagem de sobrevivência, indicaram que as taxas de sobrevivência diária dos ninhos aumenta linearmente à medida que avança a estação reprodutiva, ao passo que diminui conforme a idade do ninho aumenta. Nenhum dos fatores que testamos - altura do ninhos, tamanho dos ninhos, planta suporte e distância até a borda dos ambientes de cascalheira - mostraram-se importantes como fatores determinantes do sucesso dos ninhos. Entretanto, ninhos construídos nas plantas mais comuns na área de estudo (samambaias) apresentaram maior tendência de sucesso que os demais. Adicionalmente, não houve interferência do observador nas estimativas de sobrevivência dos ninhos. Nossos resultados sugerem que as antigas áreas de cascalheira podem ser adequadas para a reprodução do canário-rasteiro, uma vez que as taxas de sobrevivência que encontramos neste estudo são similares às encontradas em estudos com outras espécies na região central do Cerrado.
\end{abstract}

Palavras-chave: sobrevivência de ninhos, Emberizidae, habitat de reprodução, habitats degradados, savana neotropical.

\section{Introduction}

The migrant Stripe-tailed Yellow-finch (Sicalis citrina Pelzeln, 1870) inhabits rocky mountain slopes and open cerrados, and has a widespread distribution in South
America (Hilty and Brown, 1986; Ridgely and Tudor 1989; Sick 1997). In central Brazilian cerrado the species is commonly found in degraded areas (abandoned mining 
pits) during the breeding season (Dec-May; Gressler and Marini, 2011). Artificial habitats may be important for conservation and management as they provide breeding habitat diversity and may be the only option when natural habitats have been destroyed or converted due to human land use (Catry et al., 2004). However, habitats chosen by birds for nesting must exhibit features that lead to congruence between habitat preference and reproductive success (Chalfoun and Schmidt, 2012), of which nest survival is an important component (Martin, 1993a).

Nest predation is often the major cause of nesting failure in birds (Ricklefs, 1969; Martin, 1995). Many factors are traditionally invocated to explain patterns of nest predation in birds worldwide, such as nest physical characteristics (Møller, 1987), nest site and surrounding habitat features (Martin and Roper, 1988; Martin 1993a), nest height above ground (Møller, 1987; Martin, 1993b), and numerical predator's responses (Patnode and White, 1992; Sloan et al., 1998). Temporal parameters are also important, e.g. higher nest success rates can be expected, in some cases, in the end of the nesting season due to increased vegetation cover for nest concealment (Wiebe and Martin, 1998).

The breeding behavior of the Stripe-tailed Yellow-finch in abandoned mining pits gives rise to questions about the suitability of such abandoned degraded areas as breeding habitats. To assess this question we compared Stripe-tailed Yellow-finch's nest success with data from other passerines reproducing in anthropic and natural neotropical habitats. We also estimated Mayfield's $(1961 ; 1975)$ nest survival rates, and nest success in relation to some variables usually used to explain variation in daily survival rates (DSR) of birds' nests using Stripe-tailed Yellow-finches as model: (a) temporal variation across the breeding season, (b) nest age, (c) nest height, (d) nest size, (e) nest substrate (plant used for nest placement), (f) edge effect, and also controlled for (g) observer effect.

\section{Material and Methods}

\subsection{Study area}

We conducted fieldwork in central Brazilian cerrado (savanna-like habitat) at Brasília National Park (BNP; $15^{\circ}$ $\left.35^{\prime}-15^{\circ} 45^{\prime} \mathrm{S}, 48^{\circ} 05^{\prime}-48^{\circ} 52^{\prime} \mathrm{W}\right)$. This reserve covers more than 30.000 ha of typical cerrado biome vegetation, from grasslands to gallery forests, and disturbed areas that include many abandoned mining pits. Mining pits at BNP were created due to the removal of the upper soil layers during the 1950's-1960's, when the city of Brasília was under construction. This areas still have extensive soil erosion problems, notably gullies from 0.5 to $15 \mathrm{~m}$ deep. Vegetation is concentrated in the shallow part of the gullies (up to $0.5 \mathrm{~m}$ depth) and is composed mainly of ferns (Dicranopteris flexuosa (Schrad.), Gleicheniaceae), melastome shrubs (Miconia albicans (Swartz), Melastomataceae), tussock grasses and brooms (Baccharis sp. L., Asteraceae). Ferns are notably more abundant than other plants. Most of the ground surface outside the gullies is still exposed with scarce grass cover. Climate in the cerrado region is seasonal, with a dry season from April/May to September/ October. Mean annual temperature varies from $21-22{ }^{\circ} \mathrm{C}$ (ranging from $17-27^{\circ} \mathrm{C}$ ), and mean annual rainfall from 1400-1600 mm (Silva et al., 2008).

\subsection{Study species}

Stripe-tailed Yellow-finch (Sicalis citrina, Emberizidae) has a wide distribution in South America, ranging from Suriname to Argentina (Hilty and Brown, 1986; Sick 1997). It is usually found in rocky grasslands, often called "campo rupestre", and also in open cerrados, including pastures and agricultural lands (Hilty and Brown, 1986; Stotz et al., 1996; Sick, 1997, Vasconcelos et al., 2007). The species is present in central Brazilian cerrados mostly during the raining season, and is rarely found in the region during the dry season (Braz, 2008). Abandoned mining pits at BNP are the preferred breeding habitat of the species during the nesting season (Gressler and Marini, 2011). Such areas apparently act as substitute for the natural "campo rupestre" habitat most used by the species along its distribution. Nests are open-cups built mostly in ferns $(\sim 62 \%)$, but also in small shrubs $(\sim 22 \%)$ and grass tussocks $(\sim 15 \%)$, at average $30 \mathrm{~cm}$ from the ground, ranging from 0.1 to $0.6 \mathrm{~m}$ height (Gressler and Marini, 2011). Clutch size varies from two to three eggs. Incubation period lasts $11.8 \pm 0.3$ days, and nestlings fledge at about $12.8 \pm$ 0.4 days-old. Egg laying occurs on consecutive days and incubation starts after the laying of the last egg. More details on the species reproductive biology can be found in Gressler and Marini (2011).

Potential Stripe-tailed Yellow-finch nest predators with relevant importance due to their conspicuousness in the old mining areas are the Southern Caracara (Caracara plancus (Miller, 1777), Falconidae) and the Burrowing Owl (Athene cunicularia (Molina, 1782), Strigidae). Also, birds such as Greater Ani (Crotophaga ani Linnaeus, 1758), Guira Cuckoo (Guira guira (Gmelin, 1788), Cuculidae), and some passerines, such as White-banded Tanager Neothraupis fasciata (Lichtenstein, 1823), Whiterumped Tanager Cypsnagra hirundinacea (Lesson, 1831) (Thraupidae) and Curl-crested Jay Cyanocorax cristatellus (Temminck, 1823) (Corvidae) are thought to be important nest predators in the cerrado region (França et al., 2009). Potential mammalian predators include White-eared Opossum (Didelphis albiventris Lund, 1840), feral dogs (Canis familiaris Linnaeus, 1758), and small rodents.

\subsection{Nest search and monitoring}

From mid-January to early May 2007 we located active nests by searching every possible substrate in the abandoned mining pits and by observing adults' behavior. We monitored nests at three-four days intervals until fledging or failure. We considered a nest successful when nestling period lasted at least 11 days. A nest was considered depredated when eggs or nestlings too young to fledge ( $<11$ days old) disappeared from the nest between two nest checks. When we observed nests with apparently no parents' activity 
we placed a small leaf on the eggs. Thus, nest failures were ascribed to abandonment when eggs were cold and still covered with a small leaf in the next check. We also considered nests abandoned when nestlings were found dead in the nest without evidences of predation.

At nest encounter we identified plant species used as nest substrate and measured the distance from each nest to the edge of the mining pits. We also measured nest height above ground with a tape measure, and external nest diameter and height (distance between external nest bottom and nest upper border) using a caliper $( \pm 0.1 \mathrm{~mm})$. Nest size was calculated in terms of cylinder volume because externally it was the most similar geometrical shape (cylinder volume $=\pi r^{2} h$ ). We only measured nests found during the first week of incubation to avoid measuring nests deformed due to use or rainfall. We did not measure the height of seven nests used in nest survival analysis. For those nests we used the mean height value instead (Dinsmore and Dinsmore, 2007).

For each visit to nests with nestlings, we measured nestlings' wing chord, tarsus, tail and bill length with a caliper $( \pm 0.1 \mathrm{~mm})$, and weighted nestlings with a spring scale ( $\pm 0.1 \mathrm{~g}$ or $0.5 \mathrm{~g}$, according to nestlings' mass). Using measurement data of known-age nestlings we created a scale to aid in age determination of nestlings found after hatching. To determine nest age (i.e. number of days elapsed since the laying of the first egg) at encounter, we subtracted the number of eggs in nests found with incomplete clutches. For those nests we found during incubation period in which at least one nestling hatched, we estimated nest age by subtracting incubation and laying period from hatching day. In cases in which the nests we encountered were depredated during the incubation period, we estimated nest age using the following formula modified from Martin et al. (1997; Equation 1):

Nest age $=$ date found $-[($ incubation period number of days the nest was active)/2] $-\alpha$;

where date found corresponds to the day a nest was first observed active within the breeding season, and $\alpha$ corresponds to length of the laying period. For those nests found with nestlings, we estimated nest age by backdating from nestlings age, incubation and laying periods. Accurate determination of nests initiation dates are important when DSR vary according to temporal covariates such as nest age (Dinsmore et al., 2002).

\subsection{Nest survival analyses}

We used Program MARK (White and Burnham, 1999) to model Stripe-tailed Yellow-finches nests' DSR. We used Akaike's information criterion corrected for small samples (AICc) for model selection, and used logit link function and sin link function for models with and without covariates, respectively (Dinsmore et al., 2002; Rotella et al., 2004; Wilson et al., 2007). We used Akaike weights and Evidence Ratio (ER) of model pairs (ratio of Akaike weights of model pairs, wi/wj) to infer about models importance in model selection (Burnham and Anderson, 2002).
We analyzed our nest survival data in two steps following a hierarchical approach (Traylor et al., 2004; Dinsmore and Dinsmore, 2007). In the first step we evaluated temporal patterns within the nesting season by creating models with the following temporal trends: (a) constant, which corresponds to Mayfield's nest success; (b) linear; and (c) quadratic trend. To such models the variable nest age was combined to test the prediction that nest predation risk increases with nest age in response to higher activity at the nest towards the fledging date (Roper and Goldstein 1997). Nests submitted to monitoring are subject to some degree of disturbance caused by observer's activity (Lenington, 1979), possibly causing bias in the estimation of nest survival rates (Rotella et al., 2000). Thus, in the first step we also created a model in which DSR vary as function of whether or not a nest was visited on each day of the nesting season to test the possible observer effects on nest survival according to Rotella (2007). Such model considers the short-term effect of the observer's presence near the nest.

In the second step we combined four nest covariates with the best-supported models of the first step: (a) nest height, (b) nest size, (c) distance to habitat edge, and (d) plant species used for nest substrate (we created two dummy variables as individual covariates for three types of nest substrate; Rotella 2007). Additive models with all possible combinations between nest individual covariates and the best models of the first step were created.

We used model averaging to obtain robust estimates of DSR by varying the interest covariate, according to Burnham and Anderson (2002). We estimated nest survival probability for early, intermediate, and late hypothetical nests based on model-averaged estimates of DSR. As successful nests remain active for 25 days (i.e. 24 transition days) we multiplied the first 24 DSR estimates of the nesting season for early nests; for intermediate nest we used the middle 24 DSR estimates and for late nests the last 24 DSR estimates of the nesting season. We also provide Mayfield's estimates of DSR, nest survival probability, and confidence intervals based on the output of the null model of the analysis in program MARK. Mayfield's nest survival was obtained by raising Mayfield's DSR to the $24^{\text {th }}$ power.

\section{Results}

Predation was the main cause of nest failure. For the 73 nests we could determine nest fate out of 99 nests found, 48 were depredated (66\%), while six were abandoned ( $8 \%$ ), and 19 produced young (26\%), which corresponds to the Stripe-tailed Yellow-finches apparent success. Mayfield's daily survival rates and nest success were 0.94 (SE: 0.009; $\mathrm{CI}=0.92,0.96)$ and $23 \%(\mathrm{CI}=0.14,0.34)$, respectively.

Out of the 73 nests for which we determined fate, only 59 were suitable for nest survival modeling in program MARK. In the first step, two models with temporal covariates had substantial support, accounting for $91 \%$ of Akaike's weights. The best model on the first step had $65 \%$ of support (Table 1) and included a linear time trend 
$\left(\beta_{\text {linear }}=0.02, \mathrm{SE}=0.007, \mathrm{CI}=0.003,0.03\right)$ and nest age covariate $\left(\beta_{\text {nest age }}=-0.07, \mathrm{SE}=0.03, \mathrm{CI}=-0.12,0.02\right)$. These results indicate that nests are more likely to be successful towards the end of the nesting season and that the risk of nest predation increases towards fledging date. The model that includes possible observer effect on DSR had little support (Table 1).

In the second step, all four nest individual covariates were included in the best models, although Akaike's weights in these models were low (from $4 \%$ to $11 \%$ ) as well as their evidence ratios in relation to the best model (from 1.2 to 2.6). Nest height and plant species used for nest substrate $95 \%$ confidence interval (CI) considerably overlapped zero. Nest size (mean: 348,13 $\mathrm{cm}^{3}$, range: 156.93 to $570.63 \mathrm{~cm}^{3}$ ), and distance to edge (mean: $31 \mathrm{~m}$, range: 4 to $75 \mathrm{~m}$ ), despite both showed great variation among nests, had very low effect size (Table 2). Furthermore, the two best models of the second step ("linear + age + substrate" and "linear + age + height") only weakly improved the best model of the first step ("linear + age"), with low evidence ratios (ER $=1.2$ and 1.0 , respectively).

\section{Discussion}

As we did not have estimates of the Stripe-tailed Yellow-finch nest survival rates in natural habitats, we were unable to compare nest survival rates from such habitats to our study. However, our estimates of nest survival $(26 \%)$ are in the range of those found for other emberizids in the cerrado region, both in natural habitats: Coal-crested Finch Charitospiza eucosma $(20 \%$; Diniz et al. 2013), and in altered habitats: Blue-black Grassquits Volatinia jacarina (24\%; Aguilar et al. 2008), and Double-collared Seedeater Sporophila caerulescens (36\%; Francisco 2006). Stripe-tailed Yellow-finch's nest success rates, nevertheless, were considerably lower than the observed for the Grassland Yellow-Finch Sicalis luteola breeding in Brachiaria-dominated pastures (47\%; Freitas and Francisco 2012), and significantly higher than the observed for Blue-black Grassquits, also breeding in an altered habitat ( $>5 \%$; Carvalho et al. 2007). Such cases, however, apparently represent extreme values due to their discrepancies comparing to other studies in the cerrado region. Nest survival rates we found for Stripe-tailed Yellow-finch are also similar to other emberizid breeding

Table 1. Results of model selection of daily survival rates (first and second steps) of the Stripe-tailed Yellow-finches' nests at Brasília National Park, in 2007. Models with Akaike weights lower than 0.04 were omitted in the results of the second step.

\begin{tabular}{lcccc}
\hline \multicolumn{1}{c}{ Model } & $\Delta \mathbf{A I C}$ & $\mathbf{w}_{\mathbf{i}}$ & $\mathbf{K}$ & Deviance \\
\hline First step $^{\mathrm{a}}$ & & & & \\
liner + age & 0.00 & 0.65 & 3 & 205.70 \\
quadratic + age & 1.82 & 0.26 & 4 & 205.49 \\
linear & 5.64 & 0.04 & 2 & 213.36 \\
null & 6.83 & 0.02 & 1 & 216.57 \\
quadratic & 7.62 & 0.01 & 3 & 213.3 \\
observer effect & 8.80 & 0.01 & 2 & 216.52 \\
Second step & & & & \\
linear + age + substrate & 0.00 & 0.11 & 5 & 201.23 \\
linear + age + height & 0.33 & 0.09 & 4 & 203.59 \\
linear + age & 0.42 & 0.09 & 3 & 205.70 \\
linear + age + height + substrate & 1.27 & 0.06 & 6 & 200.46 \\
linear + age + size + substrate & 1.73 & 0.05 & 6 & 200.92 \\
quadratic + age + substrate & 1.84 & 0.04 & 6 & 201.03 \\
linear + age + height + size & 1.93 & 0.04 & 5 & 203.16 \\
linear + age + edge + substrate & 1.93 & 0.04 & 6 & 201.12 \\
linear + age + size & 1.94 & 0.04 & 4 & 205.19 \\
\hline
\end{tabular}

${ }^{\mathrm{a}}$ Lowest AICc value for this analysis was 211.74 ; ${ }^{\mathrm{b}}$ Lowest AICc value for this analysis was 211.32 .

Table 2. Model averaged estimates of nest individual covariates included in the second step of Stripe-tailed Yellow-finches' nest survival analysis, at Brasília National Park, in 2007.

\begin{tabular}{lcccc}
\hline \multirow{2}{*}{ Nest individual covariate } & \multirow{2}{*}{ SE } & \multicolumn{2}{c}{$\mathbf{9 5 \%}$ CI } \\
\cline { 4 - 5 } & & & Lower & Upper \\
\hline Nest substrate (grass) & -0.35 & 0.39 & -1.13 & 0.41 \\
Nest substrate (shrubs) & -0.25 & 0.35 & -0.94 & 0.42 \\
Nest height & 0.78 & 0.77 & -0.74 & 2.31 \\
Nest size & -0.0003 & 0.01 & -0.02 & 0.02 \\
Nest edge & -0.0001 & 0.02 & -0.05 & 0.05 \\
\hline
\end{tabular}


in forest and open areas in the Amazon (29\%; Oniki 1979), and in Argentina (29\%; Auer et al. 2007). Comparing to other species groups, nest survival rates we found here were also similar to open-nesters in natural cerrados (from 10 to 33\%; Lopes and Marini 2005, Medeiros and Marini 2007, Santos 2008), and in tropical forests (29\%; review in Robinson et al. 2000), as well as altered habitats in Venezuela (29\%; Ramo and Busto 1984).

Predation was the major cause of nests failure in our study, responsible for $89 \%$ of nest losses. This pattern is found in most studies worldwide and across many habitat types and different taxonomic bird groups (Ricklefs, 1969; Martin, 1993b; Howlett and Stutchbury, 1996). The lack of support of the model in the first step that considered the effect of observers' visits to the nests provided evidence for little observer bias in estimating nest survival rates in our study.

Our nest survival modeling indicated that the most important predictors of nest survival of Stripe-tailed Yellowfinches are linear time trend and nest age. Our results are contrary to what has been found in other studies in the central cerrado region (Santos, 2008; Borges and Marini, 2010) and other seasonal environments in the temperate zone (e.g. Hochachka, 1990; Verhulst et al., 1995). The linear trend we found, where nests initiated latter in the nesting season have greater chances of success, may be related to the reduction in prey availability to nest predators, as nest abundance decreased towards the end of the nesting season (Gressler and Marini, 2011). Therefore, late-nesting can be viewed as a tradeoff in the face of migration, as it incurs in a short pre-migration period for those successful late-breeders. Fully understanding of the migration patterns of the species remain uncertain; however it is known the species is not found in the central Brazilian cerrado outside the rainy season (Braz, 2008). Our data also gives support to the hypothesis derived from Skutch's (1949) that nests become more vulnerable towards the fledging date, probably in response to higher activity at the nest towards the fledging date (Roper and Goldstein 1997), and were similar to other studies performed in the neotropics (Mason, 1985; Francisco, 2006; Auer et al., 2007; Manica and Marini, 2012).

Nest substrate covariate included in the best models of the second step suggests that ferns confer slightly higher survival rates than other plant species used for nest substrate, although their 95\% CI overlapped zero. Plant species used for nest placement can vary in the way they provide concealment to the nests (Martin, 1993b; Howlett and Stutchbury, 1996) and influence nest survival (Martin and Roper, 1988). The use of ferns as the main nest substrate may be explained by higher daily survival rates found in these plants compared to other plant species, or simply because they are the most common plant species in the mining pits. Nest success can be related to the use of the most common plant species in a given habitat as nest substrate (Martin and Roper, 1988), according to the potential prey hypothesis proposed by Martin (1993a). There was a week relationship between nest height above the ground and nest predation rates, as reported by other studies (Møller, 1987; Martin, 1993b; Wilson and Cooper, 1998).

We found no edge effect on daily survival rates, despite the wide range of variation in the distance between nest sites and the mining areas edge $(4-75 \mathrm{~m})$. One study performed in savanna habitats of the cerrado region also did not find an edge effect on passerines nest survival rates (França and Marini, 2009). Conversely, higher nest predation rates on habitat edges have been found in many studies in forest habitats (Gibbs, 1991; Paton, 1994; Marini et al., 1995). The lack of edge effect in our study may be explained by the presence of the potential nest predators Burrowing Owls and Southern Caracaras throughout the old mining pits during the nesting season, regardless of the distance to habitat edge (pers. obs.). Nest size was also not an important predictor of nest success, despite their large variation in volume $\left(156.93-570.63 \mathrm{~cm}^{3}\right)$. Although nest predation may select for smaller nests in some bird species (Møller, 1990), lack of relationship between nest size and nest success was found for other passerine species (Cresswell, 1997). Thus, we suggest that variation in nest characteristics and habitat features surrounding the nests sites we measured are not determinants to such predators' accessing the nests.

Our data suggests that old mining areas in the BNP are suitable alternative breeding habitats for Stripe-tailed Yellow-finch during the nesting season, at least regarding one important bird's fitness component, nest survival (Martin 1993a). Stripe-tailed Yellow-finch nest survival rates in these areas are similar to other bird species breeding in natural habitats in the cerrado region. Suitable alternative breeding habitats may have a central role in conservation. For instance, most of the Portuguese Little Terns (Sterna albifrons Pallas, 1764) population shifted their breeding habitat from natural sandy beaches to artificial wetlands (salinas) in response to human disturbance and alteration of the natural breeding habitat (Catry et al., 2004). Although the Stripe-tailed Yellow-finch is not listed as a threatened species (BirdLife International 2013), vegetation restoration in the old mining areas can be considered as a conservation paradox for yellow-finches, since strip-mining areas are the preferred breeding site of the species in the BNP (Gressler and Marini, 2011). Further studies should focus on the adaptive response of the Stripe-tailed Yellow-finch breeding behavior using artificial habitats for nesting, regarding the disproportionate use of novel habitats, and further component of its life history, such as postfledging survival and recruitment.

\section{Acknowledgements}

This study had the support of a scholarship from CAPES (Coordenação de Aperfeiçoamento de Pessoal de Nível Superior) to D.T.G. CNPq (Conselho Nacional de Desenvolvimento Científico e Tecnológico) provided a researcher fellowship to M.Â.M. We thank the Brasília National Park administration for the study permissions. We are thankful to M. Cariello, G. R. Colli, and C. de Melo 
for criticisms of a previous version of the manuscript. We also thank N. O. M. Sousa, L. T. Manica, D. Hoffman and R. I. Dias for helping in field surveys and suggestions during the preparation of this manuscript. Finally, we are thankful to an anonymous reviewer that contributed to the final version of this manuscript.

\section{References}

AGUILAR, TM., DIAS, RI., OLIVEIRA, AC. and MACEDO, RHF., 2008. Nest-site selection by Blue-black Grassquits in a Neotropical savanna: do choices influence nest success? Journal of Field Ornithology, vol. 79, no. 1, p. 24-31. http://dx.doi. org/10.1111/j.1557-9263.2008.00142.x.

AUER, SK., BASSAR, RD., FONTAINE, JJ. and MARTIN, TE., 2007. Breeding biology of passerines in a subtropical montane forest in Northwestern Argentina. The Condor, vol. 109, no. 2, p. 321-333. http://dx.doi.org/10.1650/0010-5422(2007)109[321:BB OPIA]2.0.CO;2.

BIRDLIFE INTERNATIONAL, 2013. Sicalis citrina. In IUCN. IUCN Red List of Threatened Species. Version 2012.2. Available from: <http://www.birdlife.org $>$. Access in: 29 Apr. 2013.

BORGES, FJA. and MARINI, MÂ., 2010. Birds nesting survival in disturbed and protected Neotropical savannas. Biodiversity and Conservation, vol. 19, no. 1, p. 223-236. http://dx.doi.org/10.1007/ s10531-009-9718-z.

BRAZ, VS., 2008. Ecologia e conservação das aves campestres no Bioma Cerrado. Brasília: Universidade de Brasília. Tese de Doutorado.

BURNHAM, KP. and ANDERSON, DR., 2002. Model selection and multimodel inference: a practical information-theoretic approach. 2nd ed. Springer. $488 \mathrm{p}$.

CARVALHO, CBV., MACEDO, RHF. and GRAVES, JA., 2007. Reproduction of Blue-black Grassquits in central Brazil. Brazilian Journal of Biology = Revista Brasileira de Biologia, vol. 67, no. 2, p. 275-281. http://dx.doi.org/10.1590/S1519-69842007000200012. PMid:17876437

CATRY, T., RAMOS, JA., CATRY, I., ALLEN-REVEZ, M. and GRADE, N., 2004. Are salinas a suitable alternative breeding habitat for Little Terns Sterna albifrons? The Ibis, vol. 146, no. 2, p. 247-257. http://dx.doi.org/10.1046/j.1474-919X.2004.00254.X.

CHALFOUN, AD. and SCHMIDT, KA., 2012. Adaptive breedinghabitat selection: is it for birds? The Auk, vol. 129, no. 4, p. 589599. http://dx.doi.org/10.1525/auk.2012.129.4.589.

CRESSWELL, W., 1997. Nest predation: the relative effects of nest characteristics, clutch size and parental behaviour. Animal Behaviour, vol. 53, no. 1, p. 93-103. http://dx.doi.org/10.1006/ anbe.1996.0281.

DINIZ, P., RAMOS, DM. and CHEMIN, N., 2013. Breeding biology of Coal-crested Finches. The Wilson Journal of Ornithology, vol. 125, no. 3, p. 592-599. http://dx.doi.org/10.1676/12-166.1.

DINSMORE, SJ. and DINSMORE, JJ., 2007. Modeling avian nest survival in program MARK. Studies in Avian Biology, vol. 34, p. 73-83.

DINSMORE, SJ., WHITE, GC. and KNOPF, FL., 2002. Advanced techniques for modeling avian nest survival. Ecology, vol. 83, no. 12 , p. 3476-3488. http://dx.doi.org/10.1890/00129658(2002)083[3476:ATFMAN]2.0.CO;2.
FRANÇA, LC. and MARINI, MÂ., 2009. Teste do efeito de borda na predação de ninhos naturais e artificiais no cerrado. Zoologia, vol. 26, no. 2, p. 241-250. http://dx.doi.org/10.1590/ S1984-46702009000200006.

FRANÇA, LF., SOUSA, NOM., SANTOS, LR., DUCA, CG., GRESSLER, DT., BORGES, FJA., LOPES, LE., MANICA, LT., PAIVA, LV., MEDEIROS, RCS. and MARINI, MÂ., 2009. Passeriformes: nest predators and prey in a Neotropical Savannah in Central Brazil. Zoologia, vol. 26, no. 4, p. 799-802. http:// dx.doi.org/10.1590/S1984-46702009000400028.

FRANCISCO, MR., 2006. Breeding biology of the Doublecollared Seedeater (Sporophila caerulescens). The Wilson Journal of Ornithology, vol. 118, no. 1, p. 85-90. http://dx.doi. org/10.1676/1559-4491(2006)118[0085:BBOTDS]2.0.CO;2.

FREITAS, MS. and FRANCISCO, MR., 2012. Nesting behavior of the Grassland Yellow-Finch (Sicalis luteola) in southeastern Brazil. Ornitologia Neotropical, vol. 23, p. 341-348.

GIBBS, JP., 1991. Avian nest predation in tropical wet forest: an experimental study. Oikos, vol. 60, no. 2, p. 155-161. http:// dx.doi.org/10.2307/3544861.

GRESSLER, DT. and MARINI, MÂ., 2011. Breeding biology of the Stripe-tailed Yellow-finch (Sicalis citrina) in Central Brazilian cerrado. Ornitologia Neotropical, vol. 22, no. 3, p. 319-327.

HILTY, SL. and BROWN, WL., 1986. A guide to the birds of Colombia. Princeton: Princeton University Press. 512 p.

HOCHACHKA, W., 1990. Seasonal decline in reproductive performance of Song Sparrows. Ecology, vol. 71, no. 4, p. 12791288. http://dx.doi.org/10.2307/1938265.

HOWLETT, JS. and STUTCHBURY, BJ., 1996. Nest concealment and predation in Hooded Warblers: Experimental removal of nest cover. The Auk, vol. 113, no. 1, p. 1-9. http://dx.doi. org/10.2307/4088930.

LENINGTON, S., 1979. Predators and blackbirds: The "uncertainty principle" in field biology. The Auk, vol. 96, no. 1, p. 190-192.

LOPES, LE. and MARINI, MÂ., 2005. Low reproductive success of Campo Suiriri (Suiriri affinis) and Chapada Flycatcher (S. islerorum) in the central Brazilian Cerrado. Bird Conservation International, vol. 15, no. 4, p. 337-346. http://dx.doi.org/10.1017/ S0959270905000675.

MANICA, LT. and MARINI, MÂ., 2012. Helpers at the nest of White-banded Tanager Neothraupis fasciata benefit male breeders but do not increase reproductive success. Journal für Ornithologie, vol. 153, no. 1, p. 149-159. http://dx.doi.org/10.1007/ s10336-011-0718-x.

MARINI, MÂ., ROBINSON, SK. and HESKE, EJ., 1995. Edge effects on nest predation in the Shawnee National Forest, Southern Illinois. Biological Conservation, vol. 74, no. 3, p. 203-213. http:// dx.doi.org/10.1016/0006-3207(95)00032-Y.

MARTIN, TE., PAINE, C., CONWAY, CJ., HOCHACHKA, WM., ALLEN, P. and JENKINS, W., 1997. BBIRD Field Protocol. Missoula: Montana Cooperative Wildlife Research Unit/University of Montana.

MARTIN, TE., 1993a. Nest predation and nest sites: new perspectives on old patterns. Bioscience, vol. 43, no. 8, p. 523532. http://dx.doi.org/10.2307/1311947.

MARTIN, TE., 1993b. Nest predation among vegetation layers and habitat types: revising the dogmas. American Naturalist, 
vol. 141, no. 6, p. 897-913. http://dx.doi.org/10.1086/285515. PMid:19425994

MARTIN, TE., 1995. Avian life history evolution in relation to nest sites, nest predation and food. Ecological Monographs, vol. 65, no. 1, p. 101-127. http://dx.doi.org/10.2307/2937160.

MARTIN, TE. and ROPER, JJ., 1988. Nest predation and nestsite selection of a western population of the Hermit Thrush. The Condor, vol. 90, no. 1, p. 51-57. http://dx.doi.org/10.2307/1368432.

MASON, P., 1985. The nesting biology of some passerines of Buenos Aires, Argentina. Ornithological Monographs, vol. 36, no. 36, p. 954-972. http://dx.doi.org/10.2307/40168328.

MAYFIELD, H., 1961. Nesting success calculated from exposure. The Wilson Bulletin, vol. 73, no. 3, p. 255-261.

MAYFIELD, H., 1975. Suggestions for calculating nest success. The Wilson Bulletin, vol. 87, no. 4, p. 456-466.

MEDEIROS, RC. and MARINI, MÂ., 2007. Biologia reprodutiva de Elaenia chiriquensis (Lawrence) (Aves: Tyrannidae) em Cerrado do Brasil Central. Revista Brasileira de Zoologia, vol. 24, no. 1, p. 12-20. http://dx.doi.org/10.1590/S0101-81752007000100002.

MØLLER, AP., 1987. Egg predation as a selective factor for nest design: an experiment. Oikos, vol. 50, no. 1, p. 91-94. http:// dx.doi.org/10.2307/3565404.

MØLLER, AP., 1990. Nest Predation Selects for Small Nest Size in the Blackbird. Oikos, vol. 57, no. 2, p. 237-240. http://dx.doi. org/10.2307/3565945.

ONIKI, Y., 1979. Is nesting success of birds low in the tropics? Biotropica, vol. 11, no. 1, p. 60-69. http://dx.doi.org/10.2307/2388174.

PATNODE, AK. and WHITE, HD., 1992. Effects of habitat on avian productivity in abandoned pecan orchards in Southern Georgia. Journal of Field Ornithology, vol. 63, no. 1, p. 77-85.

PATON, PW., 1994. The effect of edge on avian nest success: how strong is the evidence? Conservation Biology, vol. 8, no. 1, p. 17-26. http://dx.doi.org/10.1046/j.1523-1739.1994.08010017.x.

RAMO, C. and BUSTO, B., 1984. Nidificación de los Passeriformes en los Llanos de Apure (Venezuela). Biotropica, vol. 16, no. 1, p. 59-68. http://dx.doi.org/10.2307/2387896.

RICKLEFS, RE., 1969. An analysis of nesting mortality in birds. Smithsonian Contributions to Zoology, vol. 9, no. 9, p. 1-47. http://dx.doi.org/10.5479/si.00810282.9.

RIDGELY, RS. and TUDOR, G., 1989. The birds of South America. University of Texas Press. 516 p. Vol. 1.

ROBINSON, WD., ROBINSON, TR., ROBINSON, SK. and BRAWN, JD., 2000. Nesting success of understory forest birds in central Panama. Journal of Avian Biology, vol. 31, no. 2, p. 151-164. http://dx.doi.org/10.1034/j.1600-048X.2000.310207.x.

ROPER, JJ. and GOLDSTEIN, RR., 1997. A test of the Skutch hypothesis: does activity at nests increase nest predation risk? Journal of Avian Biology, vol. 28, no. 2, p. 111-116. http://dx.doi. org/10.2307/3677304.

ROTELLA, JJ., 2007. Nest survival models. In COOCH, E. and WHITE, G., Program MARK: "a gentle introduction". 6th ed. p. 17.1-17.22. Available from: <www.phidot.org/software/ mark/docs/book/>.
ROTELLA, JJ., TAPER, ML. and HANSEN, AJ., 2000. Correcting nesting-success estimates for observer effects: Maximumlikelihood estimates of daily survival rates with reduced bias. The Auk, vol. 117, no. 1, p. 92-109. http://dx.doi.org/10.1642/00048038(2000)117[0092:CNSEFO]2.0.CO;2.

ROTELLA, JJ., ROTELLA, SJ. and SHAFER, TL., 2004. Modeling nest-survival data: a comparison of recently developed methods that can be implemented in MARK and SAS. Animal Biodiversity and Conservation, vol. 27, no. 1, p. 187-205.

SANTOS, LR., 2008. Biologia reprodutiva e comportamento cooperativo em ninhos de Cypsnagra hirundinacea. Brasília: University of Brasília. Dissertação de Mestrado.

SICK, H., 1997. Ornitologia brasileira. Nova Fronteira. 862 p.

SILVA, FAM., ASSAD, ED. and EVANGELISTA, BA., 2008. Caracterização climática do bioma Cerrado. In SANO, SM., ALMEIDA, SP. and RIBEIRO, JF. Cerrado: ecologia e flora. Brasília: EMBRAPA. p. 69-87.

SKUTCH, AF., 1949. Do tropical birds rear as many young as they can nourish? The Ibis, vol. 91, no. 3, p. 430-455. http:// dx.doi.org/10.1111/j.1474-919X.1949.tb02293.x.

SLOAN, SS., HOLMES, RT. and SHERRY, TW., 1998. Depredation rates and predators at artificial bird nests in an unfragmented Northern Hardwood forest. The Journal of Wildlife Management, vol. 62, no. 2, p. 529-539. http://dx.doi.org/10.2307/3802326.

STOTZ, DF., FITZPATRICK, JW., PARKER III, TA. and MOSKOVITS, DK., 1996. Neotropical Birds, ecology and conservation. University of Chicago Press. 478 p.

TRAYLOR, JJ., ALISAUSKAS, RT. and KEHOE, FP., 2004. Nesting ecology of White-winged Scoters (Melanitta fusca deglandi) at redberry lake, Saskatchewan. The Auk, vol. 121, no. 3, p. 950962. http://dx.doi.org/10.1642/0004-8038(2004)121[0950:NEO WSM]2.0.CO;2.

VASCONCELOS, MF., LOMBARDI, VT. and NETO, SD., 2007. Notas sobre o canário-rasteiro (Sicalis citrina) nas serras de Minas Gerais, Brasil. Atualidades Ornitológicas, vol. 140, p. 6-7.

VERHULST, S., VAN BALEN, JH. and TINBERGEN, TM., 1995. Seasonal decline in reproductive success of the Great Tit: variation in time or quality? Ecology, vol. 76, no. 8, p. 2392-2403. http://dx.doi.org/10.2307/2265815.

WHITE, GC. and BURNHAM, KP., 1999. Program MARK: survival estimation from populations of marked animals. Bird Study, vol. 46, no. sup001, p. S120-S139. http://dx.doi. org/10.1080/00063659909477239.

WIEBE, KL. and MARTIN, K., 1998. Costs and benefits of nest cover for ptarmigan: changes within and between years. Animal Behaviour, vol. 56, no. 5, p. 1137-1144. http://dx.doi.org/10.1006/ anbe.1998.0862. PMid:9819329

WILSON, RR. and COOPER, RJ., 1998. Acadian Flycatcher nest placement: does placement influence reproductive success? The Condor, vol. 100, no. 4, p. 673-679. http://dx.doi.org/10.2307/1369748.

WILSON, S., MARTIN, K. and HANNON, SJ., 2007. Nest survival patterns in Willow Ptarmigan: influence of time, nesting stage, and female characteristics. The Condor, vol. 109, no. 2, p. 377-388. http://dx.doi.org/10.1650/0010-5422(2007)109[377:NS PIWP]2.0.CO;2. 